\title{
Peningkatan Mutu Layanan di Kampung Homestay Borobudur Melalui Pembelajaran Bahasa Prancis
}

\author{
Sajarwa, Aprilia Firmonasari, dan Wulan Tri Astuti \\ Prodi Sastra Prancis Fakultas Ilmu Budaya, Universitas Gadjah Mada
}

Tim pengabdian kepada masyarakat:

Sajarwa, Wening Udasmoro, B.R. Suryo Baskoro, Ali Shahab, Subiyantoro, Wiwid Nurwidyohening, Cartalina Napitupulu,Hayatul Cholsy, Aprilia Firmonasari, Wulan

Tri Astuti, Siti Rahayu

\begin{abstract}
Abstrak
Pengabdian pada masyarakat, dalam tri dharma, merupakan dharma yang berkaitan langsung dengan masyarakat. Prodi Sastra Prancis FIB UGM melaksanakan pengabdian pada masyarakat dengan mengadakan pelatihan Bahasa Prancis untuk pegawai di Kampung Homestay Dusun Ngaran II Desa Borobudur. Pelatihan ini dilakukan dengan sistem tutorial yang menggunakan metode komunikatif. Hasil pelatihan ini, para pegawai homestay dapat berkomunikasi dalam bahasa Prancis dengan struktur dan ungkapan sederhana. Selain itu, Prodi Sastra Prancis juga membantu mempromosikan kampung homestay ini melalui website atau brosur berbahasa Prancis, supaya wisatawan mancanegara yang berbahasa Prancis dapat mengenal kampung ini dengan lebih baik. Kegiatan ini jga menghasilkan materi bahan ajar dan video bahasa Prancis pariwisata berbasis budaya lokal.
\end{abstract}

Kata kunci: pengabdian, pelatihan Bahasa Prancis, brosur, video

\begin{abstract}
Community engagement, in tri dharma, is a dharma that is directly related to society. Department of French Literature, Faculty of Cultural Sciences, Universitas Gadjah Mada carry out a community engagement program by conducting a French language training for employees in Kampung Homestay, Dusun Ngaran II, Borobudur Village. This training is delivered by tutorial system using communicative method. Expected result of this training is that the homestay employees can communicate in French with simple structures and phrases. In addition, Department of French Literature also helps the homestay to promote itself through a website or brochure in French, so that French-speaking foreign tourists can get to know this village better. This activity also produces teaching materials and videos of French-language tourism based on local cultures.
\end{abstract}

Keywords: community engagement, French training, brochures, video

\section{Pendahuluan}

Jumlah wisatawan mancanegara dari Prancis yang datang di Indonesia, menurut Eko Moncarre, kepala kantor Pariwisata Nasional Indonesia di Paris, menduduki peringkat kedua setelah wisman dari Inggris. Jumlah ini mengalami peningkatan sebesar 22,20\% 
selama bulan Januari sampai Oktober 2016 (http://nasional.republika.co.id/berita/ nasional/umum/17/01/13/ojp0dp366-jumlah-wisatawan-prancis-ke-indonesia-peringkatkedua). Peningkatan jumlah wisman ini merupakan indikasi yang sangat baik bagi perkembangan perekonomian di Indonesia. Hal ini disebabkan sektor pariwisata mampu berkontribusi sekitar $4 \%$ dari total perekonomian. Besarnya kontribusi tersebut membuat pemerintah Indonesia mentargetkan angka ini menjadi $8 \%$ atau dua kali lipatnya pada tahun 2019 (jumlah pengunjung ditargetkan meningkat menjadi sekitar 20 juta pertahun). Untuk memenuhi target ini, pemerintah telah dan akan mengupayakan berbagai cara, antara lain: memperbaiki infrastruktur, meningkatkan sarana teknologi, informasi dan komunikasi, meningkatkan akses kebersihan, melakukan promosi pariwisata secara daring maupun luring, serta membuat kebijakan visa gratis. Selain itu, kesiapan sumber daya manusia yang bekerja di sektor pariwisata juga perlu ditingkatkan, karena mereka lah yang akan menjadi garda depan dalam penerimaan para wisman. Oleh karena itu, pemerintah, mulai menggenjot kualitas tenaga kerja di sektor pariwisata, antara lain dengan memberikan pelatihan-pelatihan terkait dengan kompetensi pariwisata, supaya mereka menjadi tenaga kerja yang profesional baik di bidang perhotelan dan bidang perjalanan wisata. Di sisi lain, sekolah-sekolah yang bergerak di bidang pariwisata juga berusaha meningkatkan kualitas pendidikannya untuk mencetak calon-calon pekerja tingkat madya yang menguasai bidang yang digelutinya.

Prodi Sastra Prancis Fakultas Ilmu Budaya Universitas Gadjah Mada (FIB-UGM) sebagai prodi yang mempelajari bahasa asing, khususnya bahasa Prancis semestinya dapat berperan serta dalam meningkatkan kesiapan pekerja pariwisata dalam mensukseskan program peningkatan kualitas sektor pariwisata. Pendidikan tinggi wajib menerapkan "tri dharma perguruan tinggi", meliputi pengajaran, penelitian, dan pengabdian. Ketiga dharma tersebut seharusnya terpadu saling berkaitan (Panduan SPMPT, 2008). Prodi Sastra Prancis FIB-UGM mengintegrasikan ketiga unsur itu ke dalam suatu kegiatan pengabdian yang berjudul "Peningkatan Mutu Layanan di kampung Homestay Borobudur melalui pembelajaran bahasa Prancis". Kegiatan ini sesuai dengan salah satu dasar pemikiran direktorat pengabdian kepada masyarakat UGM yang menerapkan kegiatan pelayanan masyarakat dalam implementasinya berupa kegiatan program pemberdayaan masyarakat yang bermitra dengan berbagai pihak luar yang sesuai dengan visi dan misi UGM. Secara khusus, kegiatan pengabdian ini bertujuan untuk mengembangkan sistem pembelajaran bahasa Prancis Pariwisata di kampung homestay, khususnya kepada pengelola dan karyawan homestay. Kemampuan berbahasa Prancis yang memadai tentu saja akan dapat meningkatkan kepuasan para wisatawan yang berkunjung di kampung tersebut. Selain itu, prodi Sastra Prancis juga membantu dalam menterjemahkan websitehttp://www.kampunghomestay.com/ ke dalam bahasa Prancis, dan pembuatan brosur berbahasa Prancis dengan tujuan mengenalkan kampung ini kepada wisatawan yang berbahasa Prancis.

Pelatihan bahasa Prancis pariwisata yang diajarkan adalah bahasa Prancis yang berbasis budaya lokal. Mengapa budaya lokal penting dalam pengembangan sistem pembelajaran ini ? Hal ini dikarenakan bahasa dan budaya merupakan satu kesatuan yang saling mempengaruhi dan tidak bisa dipisahkan satu sama lain. Oleh karena itu, kesulitan dalam mempelajari bahasa asing disebabkan oleh kurangnya pengetahuan pembelajar terhadap aspek sosiokultural bahasa asing yang mereka pelajari. Dengan kata 
lain, secara interval, semakin banyak pengetahuan sosiokultural yang mereka miliki maka mereka akan lebih mudah memahami bahasa sasaran, kebalikannya, semakin sedikit pengetahuan sosiokultural yang dimiliki maka mereka akan lebih sulit memahami bahasa sasaran. Hal ini sesuai dengan apa yang dikatakan oleh Dubin (1986) bahwa problem mempelajari bahasa asing disebabkan dari perbedaan-perbedaan linguistis dan sosiokultural dari bahasa ibu dan bahasa sasaran. Pada situasi seperti ini maka penggunaan pendekatan yang tepat dan pemilihan bahan ajar yang sesuai dirasa dapat mengatasi permasalahan ini.

Dari latar belakang permasalah tersebut, dirasakan bahwa pelatihan bahasa Prancis di kampung homestay dusun Ngaran II Desa Borobudur Kabupaten Magelang Jawa Tengah berbasis pada bahasa Prancis berbasis budaya lokal ini penting untuk dilaksanakan. Para pelaku wisata di kampung homestay ini dilatih tata cara berkomunikasi dengan wisatawan berbahasa Prancis dengan menggunakan background pengetahuan yang berada di sekitar mereka, misalnya mengenai candi Borobudur, relief, kuliner khas magelang, dan sebagainya.

Kegiatan "Peningkatan Mutu Layanan di kampung Homestay Borobudur melalui pembelajaran bahasa Prancis" sangat penting dilakukan, karena kegiatan ini akan membentuk dan menghasilkan :

- Pelaku pariwisata yang trampil berbahasa Prancis pariwisata.

- Website dan brosur berbahasa Prancis mengenai kampung homestay Borobudur.

- Materi dan video bahan ajar mengenai bahasa Prancis pariwisata berbasis budaya lokal.

Secara garis besar, kegiatan ini memberi dampak yang positif dari segi sosial ekonomi masyarakat, dari dua sisi: pertama, dalam proses pelatihan ini tentu saja akan menambah kompetensi masyarakat khususnya pekerja pariwisata di desa Borobudur. Jika mereka mempunyai kemampuan yang handal dalam menerima tamu, maka akan berdampak secara langsung dengan tingkat kepuasan wisman ketika berkunjung ke desa tersebut. Tentu saja hal ini kedepannya secara tidak langsung akan menaikkan tingkat kunjungan wisman ke Borobudur. Kedua, pengenalan desa Borobudur melalui website dan brosur berbahasa Prancis, akan memfasilitasi pemahaman dan pengetahuan para wisatawan berbahasa Prancis akan eksistensi desa ini. Hal ini akan membawa dampak pengenalan desa Borobudur ke masyarakat mancanegara dan memungkinkan desa ini sebagai salah satu alternatif tempat wisata. Ketiga, pembuatan materi dan video bahasa Prancis pariwisata berbasis budaya lokal. Sejauh pengamatan kami, produk pembelajaran bahasa Prancis pariwisata berbasis budaya lokal ini belum ada. Mayoritas produk pembelajaran bahasa Prancis pariwisata adalah terbitan Prancis. Beberapa buku yang diterbitkan oleh penerbit lokal masih menggunakan contoh-contoh dari budaya Prancis. Sementara itu, produk pembelajaran yang berbasis budaya lokal masih belum ditemukan. Oleh karena itu, produk pembelajaran yang akan dihasilkan adalah produk yang unik dan memiliki keunggulan dibandingkan dengan produk sejenis yang sudah beredar di masyarakat. Produk pembelajaran yang dihasilkan berupa : buku metode pembelajaran, dan cd interaktif (audio dan video) berbasis budaya lokal. 


\section{Metode Pelaksanaan Pengabdian}

Metode yang digunakan dalam pengabdian ini diawali dengan survei. Survei dilakukan selama dua hari. Dari hasil survei diketahui kebutuhan masyarakat, yaitu pelatihan, web, brosur, dan video. Setelah survei, kami menyusun materi pelatihan dalam bahasa yang sesuai dengan kebutuhan, yaitu perhotelan. Selain itu, kami juga menyelenggarakan workshop pembuatan video dengan mengundang ahli. Pelaksanaan pengabdian berupa pelatihan Bahasa Prancis. Pelatihan menggunakan sistem tutorial dengan metode pembelajaran komunikatif.

\section{Hasil dan Pembahasan}

Secara keseluruhan program pengabdian kepada masyarakat yang dilakukan oleh Prodi Sastra Prancis dan mendapat dukungan penuh dari tokoh mayarakat dan pelaku pariwisata di Desa Ngaran dapat dikatakan berhasil dan sesuai dengan yang diharapkan. Masyarakat Desa Ngaran dapat menikmati hasil dari program ini dengan adanya pelatihan berbahasa Prancis dalam bidang pariwisata yang ditujukan kepada pelaku pariwisata di desa tersebut. Mereka yang awalnya sama sekali tidak dapat berkomunikasi dalam bahasa Prancis menjadi dapat berkomunikasi walaupun menggunakan ungkapanungkapan sederhana yang digunakan dalam komunikasi bidang pariwisata. Semoga apa yang telah dilakukan ini dapat memberi nilai tambah bagi masyarakat dan pada akhirnya dapat meningkatkan taraf kehidupan mereka menjadi lebih baik lagi.

Adapun kegiatan-kegiatan yang telah dilakukan dalam program ini adalah:

\section{Tabap Persiapan}

\section{Survei}

Sebelum melaksanakan program pengabdian kepada masyarakat ini, dilakukan survei terlebih dahulu agar program ini dapat menjadi program yang tepat sasaran. Survei ini dilakukan dua kali, yaitu pada tanggal 10 dan 17 November 2017. Pada survei yang pertama dilakukan diskusi dengan tokoh masyarakat dalam hal ini adalah koordinator kampung homestay. Sosialisasi program terutama metode-metode yang akan dilakukan dalam program ini didiskusikan bersama agar supaya di dalam pelaksanaannya program ini dapat berjalan dengan lancar dan bermanfaat bagi masyarakat. Survei kedua dilakukan untuk memastikan bahwa program pelatihan yang akan dilakukan berjalan dengan baik dan juga untuk melihat lokasi pelatihan serta lingkungannya dalam rangka pembuatan video dokumenter. Dengan survei ini diharapkan ketika pelaksanaan program tim pembuatan video sudah mempunyai gambaran tentang bagian-bagian atau spot-spot apa yang akan menjadi fokus sehingga hasil video diharapkan dapat maksimal dan sesuai dengan yang diharapkan.

\section{Pembuatan Bahan Ajar}

Bahan ajar yang digunakan dalam pelatihan bahasa Prancis untuk pelaku pariwisata di Kampung homestay ini dibuat berdasarkan kebutuhan masyarakat. Bahan ajar ini disesuaikan dengan lingkungan dan suasana di daerah tersebut sehingga tidak ada metode atau buku dalam bahasa Prancis yang dapat mengakomodir kebutuhan ini. 
Bahan ajar ini disusun menggunakan metode pembelajaran yang komunikatif dalam arti bahwa metode yang diberikan lebih menitikberatkan pada fungsi komunikasi. Hal-hal yang berhubungan dengan tata bahasa dan struktur kalimat tidak dibahas secara detail (Brown, 2008, hlm. 212). Ungkapan-ungkapan yang digunakan dalam komunikasi berbahasa Prancis bidang pariwisata yang lebih banyak diajarkan, seperti perkenalan, kosakata yang berhubungan dengan akomodasi perhotelan, transportasi, dan konsumsi serta percakapan sederhana. Ungkapan-ungkapan yang diberikan juga dalam kalimat yang sederhana dan mudah untuk diucapkan, seperti contoh di bawah.

\section{À LA RÉCEPTION}

Adeline : Bonjour, je m’appelle Adeline Martinez. Je vous ai appelé il y a 2 jours pour faire une réservation.

(Selamat pagi, nama saya Adeline Martinez. Saya menelepon Anda 2 hari yang lalu untuk melakukan pemesanan kamar.)

Dewi : Bonjour, Mademoiselle. Oh, oui. Mademoiselle Adeline Martinez, une chambre.

(Selamat pagi, Mbak. Oh, ya. Mbak Adeline Martinez, satu kamar.)

Adeline : C'est bien, moi.

(Ya, benar. Itu saya.)

Dewi : Et vous avez réservé pour trois nuits.

(Dan Anda telah memesan untuk 3 malam.)

Adeline : C'est exact.

(Benar sekali.)

Dewi : Voici votre clé, Mademoiselle Martinez, je vous accompagne jusqu'à votre homestay. Je vous explique demain le plan du village Homestay. Passez une bonne soirée.

(Ini kunci Anda, Mbak. Mari saya antar ke homestay Anda. Besok, saya akan menjelaskan denah Kampung Homestay ini. Semoga malam Anda menyenangkan!)

Adeline : Merci beaucoup.

(Terima kasih banyak.)

Dewi : Je vous en prie.

(Sama-sama.)

\section{Pelatihan Pembuatan Video Dokumenter}

Pelatihan ini dilakukan agar tim yang bertugas untuk membuat video dokumenter ini dapat membuat video dengan hasil yang baik. Tim yang bertugas adalah mahasiswa Sastra Prancis yang menaruh minat dalam pembuatan video namun belum berpengalaman secara profesional sehingga pelatihan ini dapat membantu mereka dan memberikan wawasan tentang tahapan-tahapan dalam proses pembuatan video dokumenter. Dalam pelatihan ini diberikan tahapan-tahapan yang harus dilakukan dan dipersiapkan sebelum proses pengambilan gambar dilakukan dan setelah proses pengambilan gambar 
dilakukan. Pelatihan ini diberikan oleh Teguh Supriyadi seorang jurnalis senior dari CNN Indonesia yang telah berpengalaman dalam membuat video dokumenter dan berpengalaman sebagai pemateri dalam berbagai pelatihan pembuatan video dokumenter.

\section{Tahap Pelaksanaan}

\section{Pelatihan Bahasa Prancis}

Pelatihan bahasa Prancis bagi pelaku pariwisata di Kampung Homestay dilaksakan dalam 2 hari yaitu pada tanggal 21 dan 22 November 2017 di Pendopo Wisma Nugraha, Desa Ngaran Borobudur. Pelatihan ini diikuti oleh penduduk Desa Ngaran terutama para pemilik homestay dan dibuka secara resmi oleh Kepala Desa Ngaran. Pelatihan ini didampingi oleh para tutor yaitu mahasiswa Sastra Prancis minimal semester 5 yang dipilih dan telah berpengalaman di dalam mendampingi pengajaran bahasa Prancis.

Metode yang dilakukan dalam pelatihan ini tidak seperti metode pengajaran di dalam kelas yang konvensional. Metode yang digunakan lebih pada pendekatan personal dalam hal ini berupa kelompok-kelompok kecil yang terdiri dari 3-4 orang, sebanyak 6 kelompok. Setiap kelompok didampingi oleh seorang tutor yang disupervisi oleh beberapa dosen. Dengan kelompok-kelompok kecil ini pelatihan diharapkan dapat lebih intensif dan hasilnya dapat seperti yang diharapkan. Pelatihan bahasa Prancis pariwisata yang diajarkan adalah bahasa Prancis yang berbasis budaya lokal. Mengapa budaya lokal penting dalam pengembangan sistem pembelajaran ini? Hal ini dikarenakan bahasa dan budaya merupakan satu kesatuan yang saling mempengaruhi dan tidak bisa dipisahkan satu sama lain. Oleh karena itu, kesulitan dalam mempelajari bahasa asing disebabkan oleh kurangnya pengetahuan pembelajar terhadap aspek sosiokultural bahasa asing yang mereka pelajari. Dengan kata lain, secara interval, semakin banyak pengetahuan sosiokultural yang mereka miliki maka mereka akan lebih mudah memahami bahasa sasaran, kebalikannya, semakin sedikit pengetahuan sosiokultural yang dimiliki maka mereka akan lebih sulit memahami bahasa sasaran. Melihat kondisi seperti ini maka penggunaan pendekatan yang tepat dan pemilihan bahan ajar yang sesuai dirasa dapat mengatasi permasalahan ini.

Nilai budaya lokal masih dirasa sangat kurang dalam sarana pembelajaran bahasa Prancis khusus Pariwisata. Banyak buku dan aplikasi pembelajaran masih mengacu pada nilai sosial dan budaya Prancis. Dapat diilustrasikan sebagai berikut : buku-buku metode ketrampilan dan teori, ataupun aplikasi pembelajaran bahasa berbasis multimedia, web ataupun android menggunakan tempat-tempat pariwisata yang ada di Prancis atau kebiasaan orang Prancis ketika berwisata. Bagi pembelajar bahasa Prancis yang belum pernah berkunjung ke Prancis, mungkin akan kesulitan untuk membayangkan apakah thalassotheraphie (terapi dengan air laut, biasanya dilakukan pada musim dingin) itu ? Topik mengenai thalassotheraphie kemungkinan akan menyulitkan bagi para pembelajar bahasa Prancis karena terapi ini jarang ditemukan dan tidak ada musim dingin di Indonesia. Daripada mengetengahkan topik thalassotheraphie ke dalam buku atau aplikasi belajar bahasa Prancis pariwisata, lebih baik jika buku atau aplikasi belajar menyajikan topik tentang lingkungan sekitar atau tentang pekerjaan yang dilakukan. Dengan mengetengahkan topik berbasis budaya lokal, pembelajar bahasa Prancis Pariwisata akan lebih mudah untuk mempelajari bahasa Prancis Pariwisata karena topik sudah ada di dalam background pengetahuan mereka. Dari ilustrasi di atas dapat diketahui 
bahwa pemahaman budaya memiliki peranan yang sangat penting dalam menentukan keberhasilan proses pembelajaran bahasa asing (Blackledge, 2005, hlm. 25). Oleh karena itu pemakaian materi otentik atau authentic-materials akan sangat membantu pembelajar dalam mempelajari bahasa asing, terutama bagi mereka yang belum pernah sama sekali mengenal budaya dari negara tersebut. Dengan mempelajari bahasa Prancis pariwisata dengan materi otentik, mereka tidak hanya mempelajari bahasa, tetapi juga dapat mengenal lebih jauh budaya Indonesia karena materi tersebut nantinya akan digunakan oleh mereka sebagai materi dalam menerima para wisman.

Pada pelatihan ini terlihat antusias peserta dan semangat mereka di dalam mengikuti pelajaran bahasa Prancis. Pada awalnya mereka sangat kesulitan untuk melafalkan kosakata bahasa Prancis, namun para tutor dengan sabar melatih mereka sehingga mereka dapat melafalkan dengan baik. Banyaknya wisatawan dari negara Prancis atau Francophone yang bermalam di Desa Borobudur ini membuat mereka sangat antusias untuk belajar bahasa Prancis. Dengan adanya pelatihan ini mereka berharap dapat berkomunikasi dalam bahasa Prancis dengan tamu-tamu mereka dengan ungkapanungkapan yang sederhana dan dapat dimengerti sehingga kesan positif dari para tamu tersebut dapat mereka peroleh.
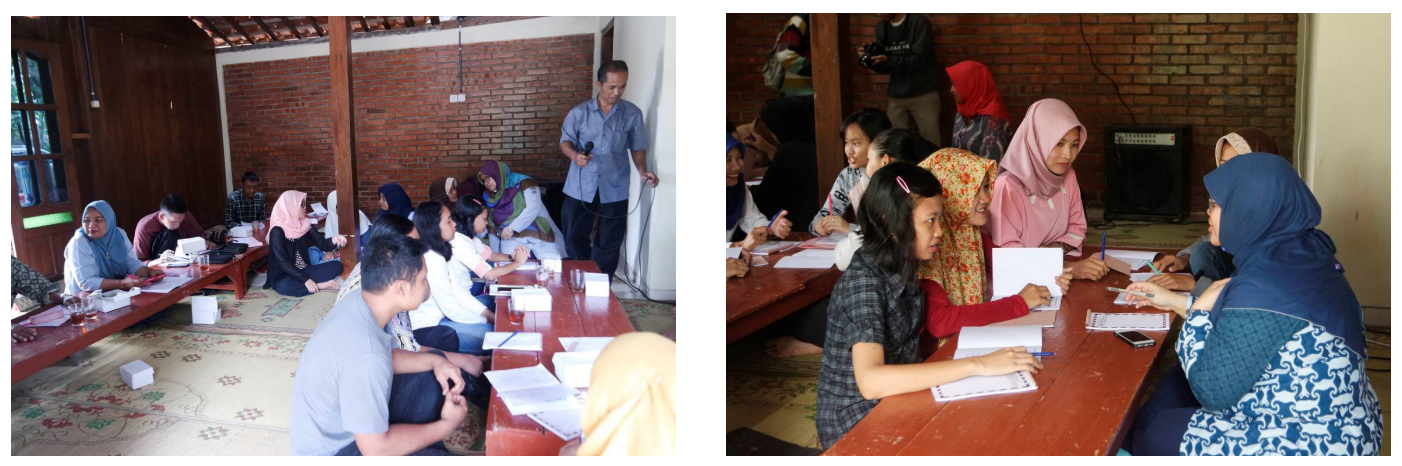

Foto 1 dan 2. Suasana pelatihan bahasa Prancis bidang pariwisata

\section{Pembuatan Video Dokumenter}

Video dokumenter tentang kegiatan pelatihan bahasa Prancis dibuat sebagai salah satu output dalam program ini dan juga sebagai ajang latihan bagi mahasiswa Sastra Prancis di dalam membuat sebuah karya dokumenter. Video dokumenter ini akan dimasukkan ke dalam web FIB UGM dan juga secara tidak langsung dapat menjadi wadah promosi Kampung Homestay Ngaran II Desa Borobudur. Di dalam video tersebut tidak hanya memuat proses pelatihan bahasa Prancis saja tetapi juga suasana desa dengan pemandangan yang bagus dan asri serta penduduknya yang ramah yang siap menerima kedatangan para wisatawan terutama wisatawan dari Prancis dan negaranegara Francophone.

\section{Pembuatan Website dan Brosur}

Untuk mendukung promosi Kampung Homestay dan menarik wisatawan dari Prancis dan negara-negara Francophone dibuat website dan brosur tentang aktivitas di kampung ini dalam bahasa Prancis. Website dan brosur ini diharapkan dapat menambah daya tarik 
Kampung Homestay ini dan semakin banyak orang yang mengenal lokasi ini sehingga akan banyak orang yang berkunjung dan menginap di lokasi tersebut.

\section{Penutup}

Adanya pengabdian yang berupa pelatihan Bahasa Prancis ini memberi harapan bagi pegawai dan pemilik homestay karena mereka berharap dapat berkomunikasi dalam bahasa Prancis dengan tamu-tamu mereka dengan ungkapan-ungkapan yang sederhana dan dapat dimengerti sehingga mendapat kesan positif dari para tamu. Kegiatan ini akan dilanjutkan pada tahun 2018 dengan sasaran para pedagang di Kampung Homestay Dusun Ngaran II Desa Borobudur. Prodi Sastra Prancis FIB-UGM sebagai prodi yang mempelajari bahasa asing berperan serta dalam menghasilkan lulusan yang mempunyai kemampuan bilingual dan bikultural sebagai pelaku pariwisata. Berdasarkan tracer study yang dilakukan, hampir 30\% lulusan bergerak di bidang pariwisata, baik di perhotelan maupun perjalanan wisata. Untuk itulah, prodi Sastra Prancis dan prodi bahasa asing lainnya perlu mengadakan kegiatan pengabdian pelatihan bahasa asing berbasis lokal di desa-desa wisata yang tersebar untuk mendukung peningkatan kunjungan wisata manca negara ke Indonesia.

\section{Daftar Pustaka}

Blackledge, Adrian. (2005). Discourse and Power in a Multilingual World. Amsterdam: John Benjamins Publishing Company.

Brown, Douglas H. (2008). Prinsip Pembelajaran dan Pengajaran Bahasa. Diterjemahkan Noor Cholis dan Yusi Arianto Pareanom. Diterbitkan oleh Kedutaan Besar Amerika Serikat Jakarta.

Direktorat Jendral Pendidikan Tinggi. (2008). Panduan Sistem Penjaminan Mutu Pendidikan Tinggi. Jakarta: Ditjen Dikti.

Dubin, Faud DE Eskey and W Grabe. (1986). Teaching Second Language: Reading for Academic Purposes. Addison: Wecley Publishing.co

http://nasional.republika.co.id/berita/nasional/umum/17/01/13/ojp0dp366-jumlahwisatawan-prancis-ke-indonesia-peringkat-kedua 